\title{
Enhancement of Festuca rubra L. germination and seedling growth by seed treatment with pathogenic Agrobacterium rhizogenes
}

\author{
Paulina Król · Jolanta Adamska · Ewa Kępczyńska
}

Received: 25 June 2014/Revised: 2 September 2014/ Accepted: 25 September 2014/Published online: 15 October 2014

(C) The Author(s) 2014. This article is published with open access at Springerlink.com

\begin{abstract}
The study concerned effects of two methods of red fescue seeds treating with wild type Agrobacterium rhizogenes strains (15834 and LBA 1334): soaking and matriconditioning with Micro-Cel E solid carrier. The effects were assessed from germination and seedlings growth rates. The bacterial indole-3-acetic acid (IAA) production and ACC deaminase activity were also determined. Both strains are able to produce the IAA and showed ACC deaminase activity in various amounts. The strains accelerated seeds germination, seedling emergence and development. The beneficial effect on those processes was visible when seeds were soaked for $1 \mathrm{~h}$ in bacterial suspension and, especially, when the bacteria were present during Micro-Cel E conditioning. The main effect observed upon inoculation of seeds during priming was increased growth of lateral roots and more complex architecture of the branching root system. Treating seeds with A. rhizogenes simultaneously with Micro-Cel E priming as a carrier is a promising method of enhancing grass germination and seedlings growth, particularly by improving the root system development.
\end{abstract}

Communicated by E. Kuzniak-Gebarowska.

P. Król · J. Adamska · E. Kępczyńska $(\bowtie)$

Chair of Plant Biotechnology, Faculty of Biology,

University of Szczecin, Wạska 13, 71-415 Szczecin, Poland

e-mail: ekepcz@univ.szczecin.pl; ekepcz@wp.pl

P. Król

e-mail: krolpaulina@poczta.fm

J. Adamska

e-mail: jolantaadamska@poczta.fm
Keywords Agrobacterium rhizogenes strains - Bio- and matri- priming - Grass growth promotion - IAA production - ACC deaminase activity

\section{Introduction}

Rapidity and uniformity of seedling emergence are the two crucial characteristics of turf grasses which contribute to good quality and durability of lawns. The red fescue (Festuca rubra L.), a cool-season, sod-forming grass is a species most commonly used for lawns. This excellent soil binder is used as a turf for lawns, athletic fields, golf courses and playgrounds. A poor seedling emergence leads to a poor turf grass stand, and, in consequence, requires additional time and money before an area can be used. It is very important, particularly under sub-optimal conditions, to reduce the time span between seeding and seedling emergence.

A technique that would improve germination and emergence performance under a wide range of environmental conditions could be of a great benefit to turf grass establishment. Such a technique is offered by seed priming. It is a pre-sowing treatment which controls the hydratation process during imbibition and following incubation; in consequence, it improves seed vigour by ensuring a rapid and uniform germination, a high final germination percentage and seedling vigour (Yamamoto et al. 1997). The matric priming termed the solid matrix priming (SMP) is widely used as a commercial seed treatment for vegetables and ornamental plants (Khan 1992). The substances used as carriers for seed matriconditioning include a synthetic calcium silicate named Micro-Cel E.

In addition to matriconditioning, there is a growing interest worldwide in manipulating rhizosphere microorganisms 
(rhizobacteria) to improve germination and seedling emergence. According to Whipps (2001), interactions between the rhizobacteria and growing plants can be neutral, negative or positive. The bacteria beneficial for plants, termed plant growth-promoting rhizobacteria (PGPR), can stimulate plant growth when grown in association with the host plant.

Application of rhizobacteria as a seed coating to improve seedling growth has been reported by numerous authors (Khan et al. 1990; Glick 1995; Lucy et al. 2004; Gholami et al. 2009). The PGPR used include genera such as Bacillus, Pseudomonas, Erwinia, Serratia, Arthobacter, Microccocus, Flavobacterium, Azotobacter, Azospirillum, Rhizobium and Agrobacterium (Verma et al. 2010). Although mechanisms of direct or indirect plant growth promotion by PGPR are not fully understood yet, several explanations have been proposed. Direct stimulation may include ability to synthesize phytohormones, e.g. gibberellins, cytokinins and auxins as well as activation or reduction of gaseous phytohormone ethylene by the activity of bacterial ACC deaminase. Among the hormones, of a particular interest are auxins because of their important role in the initial processes of lateral and adventitious root formation and root elongation (Bhattacharyya and Jha 2012). Agrobacterium of the family Rhizobiaceae was the first plantassociated bacteria in which IAA biosynthesis pathways were studied. Agrobacterium rhizogenes, a soil, gram-negative bacteria is not only capable of synthesizing IAA from tryptophan, but also, in a range of dicotyledonous plants, can enter a plant through fresh wounds and cause a root disease (Chilton et al. 1982; Tepfer 1990). Host plants inoculated by these bacteria will develop typical symptoms of the hairy root disease, i.e. diageotropic roots with numerous root hairs produced at the infection sites. The root induction is due to the integration and subsequent expression of a portion of bacterial DNA (T-DNA) from the Ri (Root inducing) plasmid in the plant genome (Grant et al. 1991). The transferred DNA (T-DNA) is integrated into the plant cell genome and, in consequence, the plant produces copious growth hormones (auxins and cytokinins) and opines which are beneficial for the bacterial growth. Several authors reported successful rooting in fruit trees and woody plants when using wild strains of $A$. rhizogenes (Damiano and Monticelli 1998; Haggman and Aronen 2000; Sarmast et al. 2012). The IAA produced by bacteria colonizing the plant rhizosphere is considered to act in conjunction with endogenous IAA in plant to stimulate root proliferation and elongation, resulting in a more branched root system architecture, which in effect enhances the host's uptake of minerals and nutrients from the soil (Spaepen et al. 2007; Shokri and Emtiazi 2010).

When seeking a method to increase the PGPR efficacy, one of the most important and effective steps is finding the best bacteria available. Microbial inoculants can be applied
(1) at seed processing as a seed coating, months before the actual sowing, (2) "on site" as a seed application just before sowing or by inoculant delivery directly onto seeds in the furrow (the most popular method), and (3) after seedlings have emerged (Bashan 1998; Martinez-Viveros et al. 2010). The bacteria can be applied singly to seeds (bio-priming) and also in combination with priming with the GrowSorb solid carrier (Khan et al. 1990) or in a drum priming system (Bennett and Whipps 2008).

The purpose of this work was to integrate and apply simultaneously two techniques: bio-priming with $A$. rhizogenes agropine strains LBA 1334 and 15834, and matripriming using Micro-Cel $\mathrm{E}$ as a carrier, to improve seed performance of the grass $F$. rubrum L. cv. Areta. We intended to check if: (1) strains 15834 and LBA 1334 are able to produce IAA and whether they show ACC deaminase (ACCD) activity, and (2) that ability is correlated with red fescue seed germination and seedling growth, including the root system development.

\section{Materials and methods}

\section{Seeds and bacteria}

The study involved $F$. rubra L. cv. Areta seeds harvested in 2008, purchased from TORSEED Seed Company (Poland) and stored dry at $-23{ }^{\circ} \mathrm{C}$ until used.

The A. rhizogenes wild strains 15834 and LBA 1334 were received from the Chair of Biotechnology of the Intercollegiate Faculty of Biotechnology, University of Gdańsk, Medical University of Gdańsk (Poland). Both strains of bacteria were cultured from glycerol stocks on the solid Luria-Bertani (LB) medium (Miller 1976) at $28{ }^{\circ} \mathrm{C}$. Bacterial isolates were transferred to the liquid Luria-Bertani Broth (LBB) medium and incubated on a rotary shaker at $25^{\circ} \mathrm{C}$ in the dark until the suspension optical density (OD) reached 0.5 at $550 \mathrm{~nm}$ wavelength.

\section{IAA production by bacteria}

For auxin production, the A. rhizogenes strains 15834 and LBA 1334 were grown to the exponential phase in the LBB medium. When the isolate OD reached 0.5 at $550 \mathrm{~nm}$ wavelength, $1 \mathrm{ml}$ of the bacterial suspension was transferred to $20 \mathrm{ml} \mathrm{LBB}$ medium supplemented with filter-sterilized $(0.2 \mu \mathrm{m}$ membrane filter, Whatman No. 2) L-tryptophan solution (L-TRP $0.5 \%$ ). L-TRP solution was added to the medium to bring the final concentration to $200 \mu \mathrm{g} / \mathrm{ml}$. Both bacterial strains were grown, shaken at $200 \mathrm{rpm}$, for 2 days at $28{ }^{\circ} \mathrm{C}$ (Khalid et al. 2004). After incubation, the reaction was terminated by adding $2 \mathrm{ml}$ trichloroacetic acid (5\%) to the flask contents. The supernatant was recovered by 
centrifugation for $30 \mathrm{~min}$ at $5,000 \mathrm{rpm}$ at $4{ }^{\circ} \mathrm{C}$, and used to determine the auxin production. The bacterial dry weight was determined by resuspending the pellet in $1 \mathrm{ml}$ distilled water and drying overnight at $70{ }^{\circ} \mathrm{C}$.

$3 \mathrm{ml}$ of the supernatant were added to a test tube and vigorously mixed with $2 \mathrm{ml}$ of the Salkowski colouring reagent $\left(2 \mathrm{ml}\right.$ of $0.5 \mathrm{M} \mathrm{FeCl}_{3}$ were mixed with $98 \mathrm{ml}$ of $35 \%$ perchloric acid) as described by Sarwar et al. (1992). After the mixture was allowed to stand at room temperature for $30 \mathrm{~min}$ for colour development, absorption was measured at $535 \mathrm{~nm}$ in a Shimadzu UV-VIS UV-1800 spectrophotometer (Patten and Glick 2002). The auxin concentration in each culture medium was calculated from a standard curve plotted for pure IAA (Sigma-Aldrich), and was reported as $\mu \mathrm{g} \mathrm{IAA} / \mathrm{mg} \mathrm{DW}$.

\section{Bacterial ACC deaminase activity assay}

Bacterial strains were cultured, shaken at $200 \mathrm{rpm}$, in the LB medium at $28{ }^{\circ} \mathrm{C}$ for $24 \mathrm{~h}$ until cell proliferation reached the stationary phase (OD 600 about 2.0). Next, the cells were collected by centrifugation at $6,000 \mathrm{~g}$ for $10 \mathrm{~min}$ at $4{ }^{\circ} \mathrm{C}$, rinsed twice with M9 minimal salts (without a nitrogen source), and subsequently resuspended in $10 \mathrm{ml}$ of modified M9 minimal medium with $5 \mathrm{mM} \mathrm{ACC}$ and incubated at $200 \mathrm{rpm}$ for $40 \mathrm{~h}$ at $28{ }^{\circ} \mathrm{C}$ with shaking as described by $\mathrm{Hao}$ et al. (2007). The ACC deaminase activity was measured in bacterial extracts prepared as described by Penrose and Glick (2003) and determined by measuring the production of $\alpha$-ketobutyrate using a standard curve of the substrate between 0.1 to $1 \mu \mathrm{M}$ (Honma and Shimomura 1978).

\section{Protein content determination}

The protein content of the enzyme extract was determined by the dye binding method using Bradford Reagent (Sigma-Aldrich) and bovine serum albumin (SigmaAldrich) as a standard (Bradford 1976).

Seed treatment

The effect of $A$. rhizogenes was determined by using strains 15834 and LBA 1334 and exogenous IAA at two concentration calculated based on the amount of the hormone produced by the two strains (IAA $1-2.3 \mu \mathrm{g} / \mathrm{ml}$, IAA $2-0.38 \mu \mathrm{g} / \mathrm{ml}$ ). The seeds were soaked in water (control), in a bacterial suspension (OD 0.5 at $550 \mathrm{~nm}$ ) or in IAA solutions for $1 \mathrm{~h}$, and then were fast-dried on sterile filter paper. The seeds thus prepared were immediately used for germination and seedling growth analysis.

For matriconditioning (MC) experiments, the seeds were mixed with synthetic calcium silicate hydrate (Micro-Cel E from Celite Corporation, Lompoe, California, USA) and water (control), bacterial suspensions (OD 0.5 at $550 \mathrm{~nm}$ ) and IAA solutions at concentrations shown above (IAA1, IAA2) at 1:0.4:0.8 weight (g) ratios, respectively; they were placed in glass jars with loosely placed caps and kept at $15^{\circ} \mathrm{C}$ in light. After 5 days of $\mathrm{MC}$, the seeds were separated from Micro-Cel E by sieving, and were fast-dried on sterile filter paper. The seeds thus treated were used in experiments described below.

Seed germination and seedling growth analysis

For seed germination, five replicates of 50 seeds treated with the methods described above were placed in 5-cm Petri dishes on a sterilized single-layer filter paper (Whatman No. 1) moistened with distilled water $(1.5 \mathrm{ml})$; the seeds were incubated in a growth chamber at $25{ }^{\circ} \mathrm{C}$. The dynamics of seed germination in darkness was determined after 3, 7 and 14 days. For seedling growth, a gnotobiotic system involving Petri dishes as pouches was used. Non-conditioned and conditioned seeds, 25 of each, were placed in $14 \mathrm{~cm}$ diameter Petri dishes on three layers of filter paper moistened with distilled water $(15 \mathrm{ml})$ and were covered with sterilized filter paper sheets. The plates were incubated in a growth chamber at $25^{\circ} \mathrm{C}(15 \mathrm{~h}$ of light, $500 \mu \mathrm{mol} \mathrm{m} / \mathrm{s}$ supplied daily); after 7 days, lengths of whole seedlings, roots and blades were measured. Fourteen days after sowing, the seedlings were weighed fresh, the seedling dry weight was determined following drying at $105^{\circ} \mathrm{C}$ for $25 \mathrm{~h}$.

\section{Seedling emergence in soil}

For seedling emergence, the treated seeds ( $1 \mathrm{~g}$ ) were sown in a sterile $2: 1: 1$ soil/perlite/vermiculite mix in plastic pots; the pots were placed at $25{ }^{\circ} \mathrm{C}$ in a growth room (15/9 day/ night photoperiod, $500 \mu \mathrm{mol} \mathrm{m} \mathrm{m}^{2} / \mathrm{s}$ supplied daily).

Statistical analysis

Each experiment was run in five replicates and repeated twice. The statistical treatment of the data involved the analysis of variance (ANOVA) using Statistica for Windows v6.0 software (Statsoft Inc., Tulsa, OK, USA). Differences between means were considered significant at $p<0.05$, as indicated by Duncan's multiple-range test.

\section{Results}

Bacterial IAA production and ACC deaminase activity

The two strains of $A$. rhizogenes used showed a very low ability $(0.008$ and $0.005 \mu \mathrm{g} / \mathrm{mg} \mathrm{DW}$, respectively; 
Fig. 1 IAA production in the presence of $200 \mu \mathrm{g} / \mathrm{ml}$ tryptophan (a) ad ACC deaminase activity in the presence of $5 \mathrm{mM}$ ACC (b) in A. rhizogenes strains 15384 and LBA 1334 after $48 \mathrm{~h}$. Vertical bars indicate \pm SD. Means with identical letters are not significantly different at $p<0.05$ (Duncan's multiple range test) a

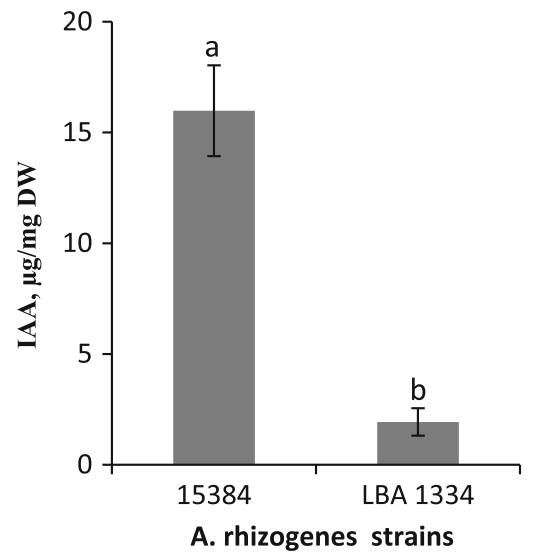

b

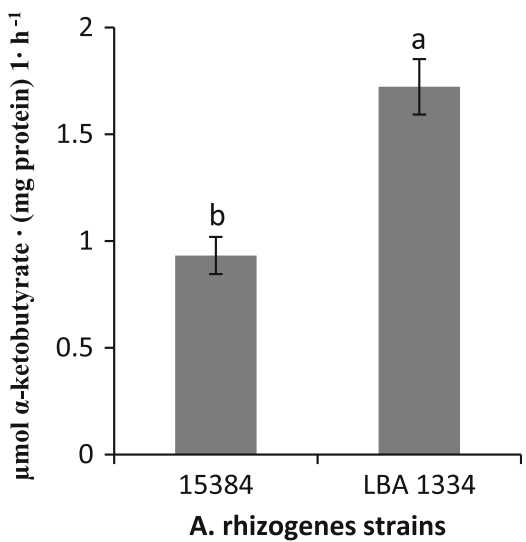

data not shown) to produce IAA in the absence of its precursor, L-tryptophan. However, when the strains were grown for $48 \mathrm{~h}$ in the presence of $200 \mu \mathrm{g} / \mathrm{ml}$ of tryptophan, their capacity to produce IAA was observed to significantly increase (Fig. 1a). The amount of IAA produced varied among the strains. The A. rhizogenes strain 15834 produced 8 times more IAA $(15.98 \mu \mathrm{g} / \mathrm{mg}$ DW) than LBA 1334 (1.93 $\mu \mathrm{g} / \mathrm{mg}$ DW).

The two strains were found to contain ACC deaminase (ACCD), an enzyme responsible for conversion of ACC, the ethylene precursor in plants, to $\alpha$-ketobutyrate and ammonia (Fig. 1b). The ACCD activity of strain 15834 kept in submerged cultures with $5 \mathrm{mM}$ ACC as the sole nitrogen source was found to be $0.92 \mu \mathrm{mol} \alpha$-ketobutyrate/ $\mathrm{mg}$ protein/h after 2 days. It was about 2 times lower than the activity of the enzyme in LBA $1334(1.72 \mu \mathrm{mol} \alpha$ ketobutyrate/mg protein/h). No ACCD activity was detected in either strain cultured in the liquid medium without ACC.

Effects of A. rhizogenes strains and exogenous IAA application on germination and seedling growth

The two A. rhizogenes strains tested in vitro for auxin biosynthesis and deaminase activity were further screened for their growth promoting effects on the red fescue seed germination and seedling growth. Observations were carried out under gnotobiotic conditions in Petri dishes in which the impact that a bacterium has on plant growth is a direct consequence of the plant-bacterial interaction and is independent of the chemical composition of the soil. A similar experiment was also conducted in soil (pot trials in the growth room). To compare effects of seed inoculation with the two strains tested with the ability to produce IAA and of exogenous application of IAA at concentrations corresponding to
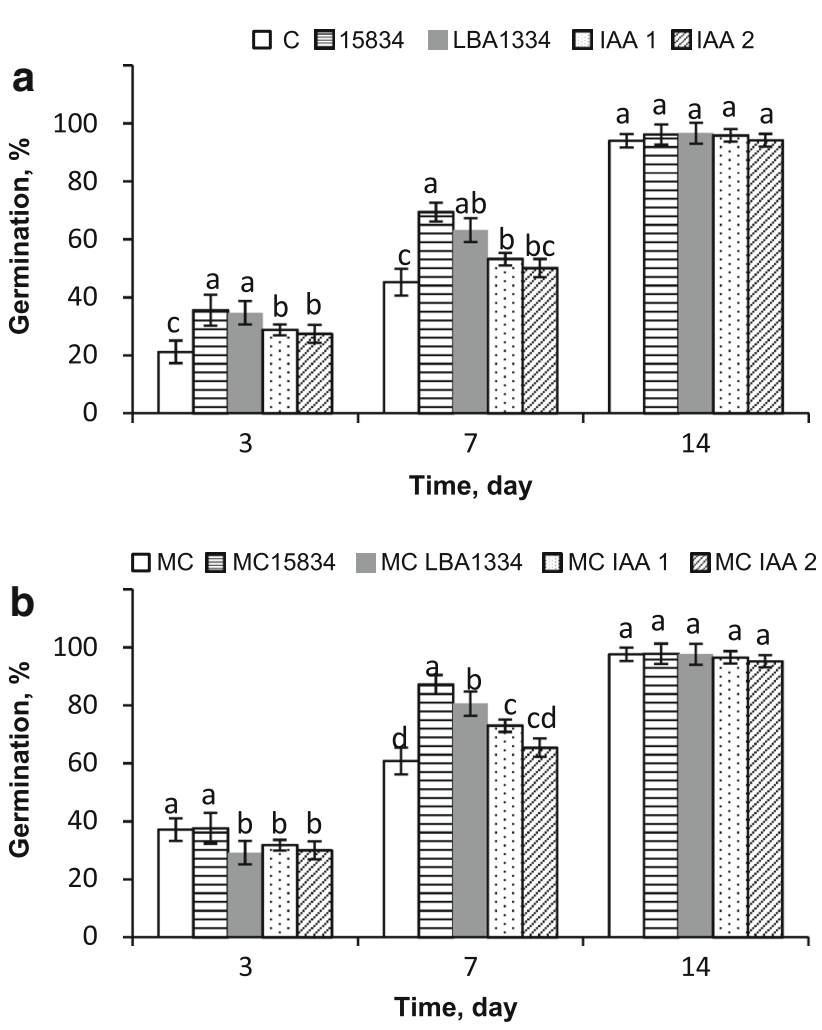

Fig. 2 Germination of red fescue seeds preincubated $1 \mathrm{~h}$ in bacterial suspension/IAA solutions (a) and preconditioned for 5 days in the presence of Micro-Cel E and bacterial suspension or IAA solutions (b). $C$ control, 15834 A. rhizogenes strain 15834, LBA1334 A. rhizogenes strain LBA1334, IAA 1 IAA $2.3 \mu \mathrm{g} / \mathrm{ml}$, IAA 2 IAA $0.38 \mu \mathrm{g} / \mathrm{ml}, M C$ matriconditioning, MC15834 A. rhizogenes strain $15834+$ MC, MCLBA1334 A. rhizogenes strain LBA1334 + MC, MC IAA 1 IAA $2.3 \mu \mathrm{g} / \mathrm{ml}+\mathrm{MC}$, MC IAA 2 IAA $0.38 \mu \mathrm{g} / \mathrm{ml}+\mathrm{MC}$. Seeds germinated in darkness at $25{ }^{\circ} \mathrm{C}$. Vertical bars indicate \pm SD. Means with identical letters are not significantly different at $p<0.05$ (Duncan's multiple range test)

IAA production by the strains, the seeds were treated by soaking for $1 \mathrm{~h}$ or 5 -day conditioning in the presence of the Micro-Cel E solid carrier. 


\section{Seed germination}

Soaking of $F$. rubra L. seeds for $1 \mathrm{~h}$ prior to the seed germination test in two bacterial suspensions resulted in accelerated germination (Fig. 2a). After 3 days of germination in the dark, the percentage of germinated seeds was higher in the seeds treated with bacterial strains than in the non-inoculated control seeds (Fig. 2a). This beneficial effect became more pronounced after 7 days: compared to the control seeds, about 24 and $18 \%$ more pre-treated (with strains 15384 and LBA 1334, respectively) seeds germinated. The germination rate in the seeds soaked for $1 \mathrm{~h}$ in IAA solutions at the concentrations calculated according to IAA production by the strains [15834 $-2.3 \mu \mathrm{g} / \mathrm{ml}$ (IAA1) and LBA $13340.38 \mu \mathrm{g} / \mathrm{ml}$ (IAA2)] was found to exceed, after 3 days, the control level by only about 12 and $6 \%$, respectively. Moreover, after 7 days, it was only the higher IAA concentration (IAA2, $2.3 \mu \mathrm{g} / \mathrm{ml}$ ) that exerted a slightly stimulatory effect. After 14 days, all the seeds, both the control and those treated with bacteria/ IAA, reached the final extent of germination which exceeded $94 \%$.

Seed conditioning for 5 days in the presence of calcium silicate hydrate (Micro-Cel E) was observed to stimulate seed germination after 3 days (Fig. 2b); about $16 \%$ more seeds germinated compared with the non-conditioned control (Fig. 2a). The presence of bacteria or IAA during conditioning had no beneficial effect on germination after 3 days, but after 7 days of germination gave promising results (Fig. 2b). Subsequently, when about $45 \%$ of the control (Fig. 2a) and $61 \%$ of the matriconditioned seeds had germinated, 87 and $81 \%$ of the matriconditioned seeds were observed to germinate in the presence of 15834 and LBA 1334 bacterial suspension, respectively (Fig. 2b). Seed conditioning in presence of IAA, too, exerted a stimulatory effect on seed germination, although the effect was lower than that of the bacterial strains. Treating the seeds with a higher concentration $(2.33 \mu \mathrm{g} / \mathrm{ml})$ of exogenous IAA during matriconditioning had a stimulatory effect on seed germination, as about $12 \%$ more seeds germinated compared with the seeds conditioned in the presence of Micro-Cel E only. After 14 days all the seeds, conditioned solely in the presence of Micro Cel-E or with both Micro-Cel E and bacteria strains/IAA, reached their final extent of germination which exceeded $97 \%$.

\section{Seedling growth}

All the seed pretreatments described above were screened for their growth-promoting effects by conducting Plate
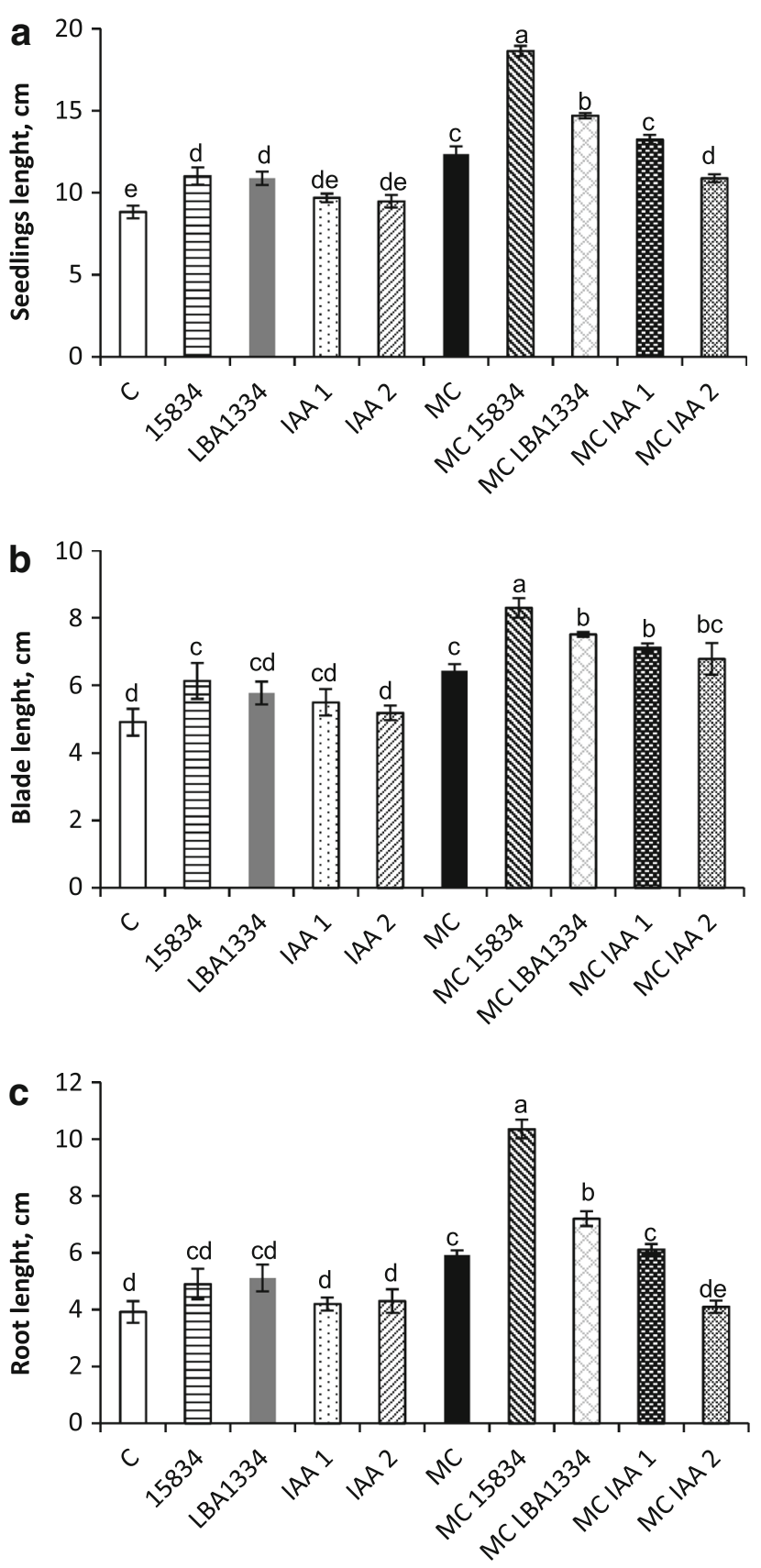

Fig. 3 Growth of 7-day-old red fescue seedlings (a), blades (b) and roots (c) obtained from seeds preincubated for $1 \mathrm{~h}$ in bacterial suspension or IAA solutions and seeds preconditioned for 5 days in the presence of Micro-Cel $\mathrm{E}$ and bacterial suspension/IAA solutions. Gnotobiotic experiment. The seedlings were grown in growth chamber (15/9 day/night photoperiod) at $25{ }^{\circ} \mathrm{C}$. $C$ control, $15834 \mathrm{~A}$. rhizogenes strain 15834, LBA1334 A. rhizogenes strain LBA1334, IAA 1 IAA $2.3 \mu \mathrm{g} / \mathrm{ml}, I A A 2$ IAA $0.38 \mu \mathrm{g} / \mathrm{ml}, M C$ matriconditioning, MC15834 A. rhizogenes strain $15834+$ MC, MCLBA1334 A. rhizogenes strain LBA1334 + MC, MC IAA 1 IAA $2.3 \mu \mathrm{g} / \mathrm{ml}+$ MC, MC IAA 2 IAA $0.38 \mu \mathrm{g} / \mathrm{ml}+\mathrm{MC}$. Vertical bars indicate \pm SD. Means with identical letters are not significantly different at $p<0.05$ (Duncan's multiple range test) 


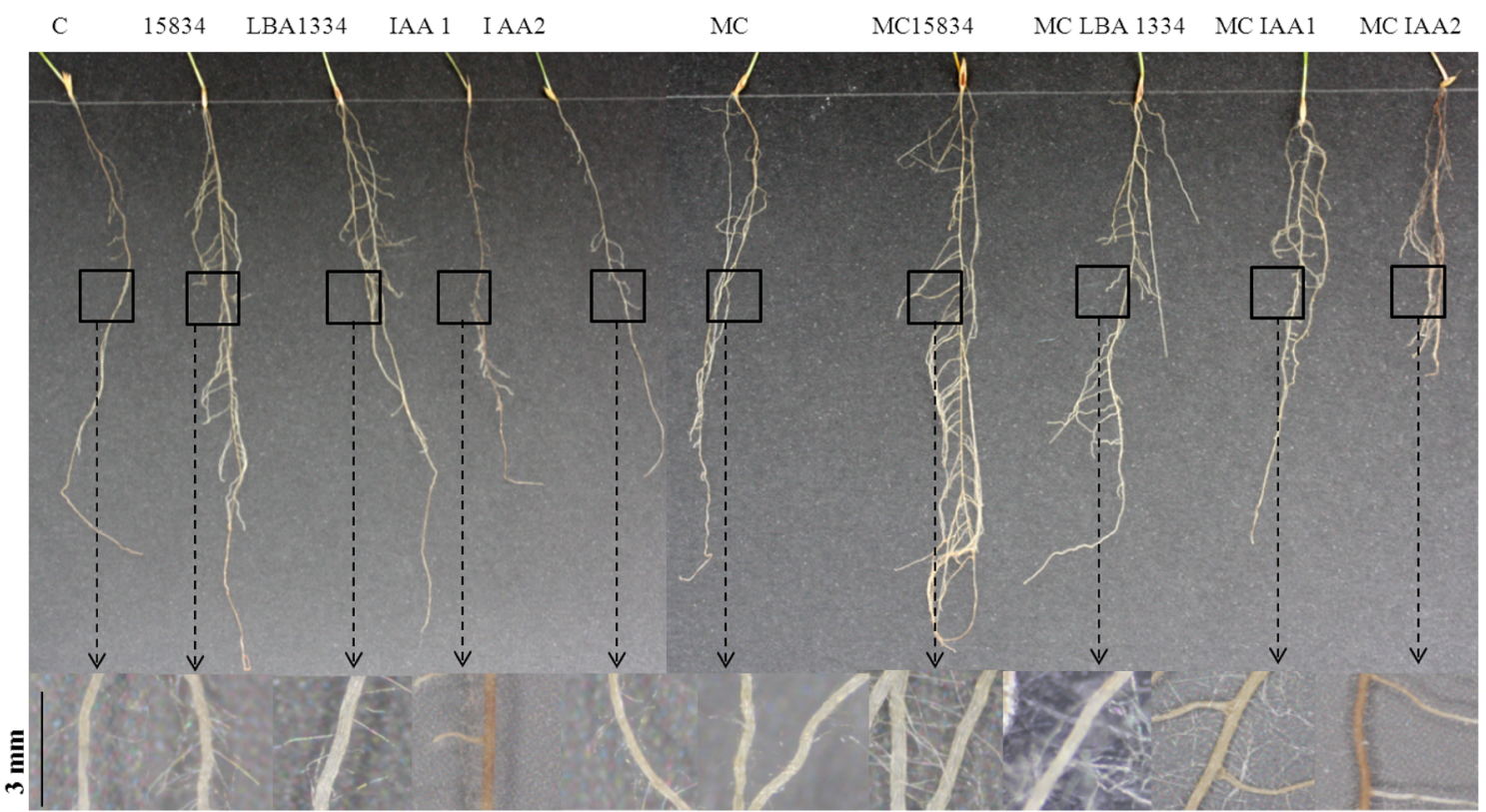

Fig. 4 Effect of $1 \mathrm{~h}$ red fescue seed soaking in bacterial suspension/ IAA solutions and seed preconditioning for 5 days in the presence of Micro-Cel E and bacterial suspension/IAA solutions on the growth of roots after 7 days in growth chamber (15/9 day/night photoperiod) at $25{ }^{\circ} \mathrm{C}$. C control, 15834 A. rhizogenes strain 15834, LBA1334 A.

(gnotobiotic) and pot (soil) experiments under controlled conditions in growth chambers ( $15 \mathrm{~h}$ light/ $9 \mathrm{~h}$ dark). Under gnotobiotic conditions, 7-day-old red fescue seedlings obtained from seeds preincubated for $1 \mathrm{~h}$ in suspensions of strains 15834 and LBA 1334 were significantly longer compared to the control (Fig. 3a). The whole seedlings from the two pretreatments were by about 2.3 and $2.1 \mathrm{~cm}$ (25 and $23 \%$ ) longer than the control seedlings, respectively, whereas soaking the seeds in IAA solution did not significantly increase the seedling length. The beneficial effect of the bacterial strains was more visible when they were present during the 5-day conditioning of seeds with Micro Cel E; the seedlings were by 112 and $67 \%$ longer than the control seedlings, respectively. The presence of $2.3 \mu \mathrm{g} / \mathrm{ml}$ IAA (IAA1) during seed conditioning with Micro-Cell E produced stimulatory effect on seedlings growth as well, but the effect was lower compared to that of priming with bacterial strains: the seedlings were by $50 \%$ longer than the control seedlings and were of nearly identical length as the seedlings obtained from seeds conditioned in the presence of Micro-Cel E only. Application of $0.38 \mu \mathrm{g} / \mathrm{ml}$ IAA (IAA2) retarded the seedling growth if the growth is compared with that of seedlings from matricoditioned seeds, although they were by about $35 \%$ longer that the control seedlings. Only those seedlings developed from seeds soaked in suspension of strain 15834 had longer blades, by about $1.2 \mathrm{~cm}$ compared to the control (Fig. 3b), whereas the presence of the bacteria during rhizogenes strain LBA1334, IAA 1 IAA $2.3 \mu \mathrm{g} / \mathrm{ml}$, IAA 2 IAA $0.38 \mu \mathrm{g} / \mathrm{ml}, M C$ matriconditioning, MC15834 A. rhizogenes strain 15834 + MC, MCLBA1334 A. rhizogenes LBA1334 strain + MC, MC IAA 1 IAA $2.3 \mu \mathrm{g} / \mathrm{ml}+\mathrm{MC}$, MC IAA 2 IAA $0.38 \mu \mathrm{g} / \mathrm{ml}+\mathrm{MC}$

matriconditionig significantly enhanced the blade growth; the blades were by about $3.4 \mathrm{~cm}$ longer than in the control. The presence of another bacterial strain, LBA 1334, and exogenous IAA during conditioning enhanced the blade growth as well, but the enhancement was less pronounced: the blades were by $2.6,2.2$ and $1.9 \mathrm{~cm}$ longer than the control blades, respectively. Matriconditionig of seeds alone without bacteria and IAA had also stimulatory effect on the growth seedling blades which were by about $1.5 \mathrm{~cm}$ longer that in the control.

All the seedlings had longer blades (Fig. 3b) than roots (Fig. 3c), except for those seedlings obtained from seeds matriconditioned in the presence of strain 15834. The 7-day-old seedlings from seeds inoculated, during matriconditionig, with $A$. rhizogenes strain 15834 grew roots by about $2 \mathrm{~cm}$ longer than blades $(10.35$ and $8.30 \mathrm{~cm}$, respectively). The roots were about 2.6 times longer than the control seedling roots (Fig. 3c). The roots of the seedlings obtained from seeds matriconditioned in the presence of strain LBA 1334 were longer, too; they were about twice as long as the roots in the control seedlings (Fig. 3c). The roots of seedlings grown from seeds conditioned in the presence of Micro Cel $\mathrm{E}$ only and both Micro Cel E and IAA ( $2.3 \mu \mathrm{g} / \mathrm{ml})$ had nearly the same length (5.9 and $6.1 \mathrm{~cm}$, respectively), but they were longer compared to roots in the control $(3.9 \mathrm{~cm})$.

Inoculation of grass seeds by soaking or during conditioning with the two A. rhizogenes strains not only 

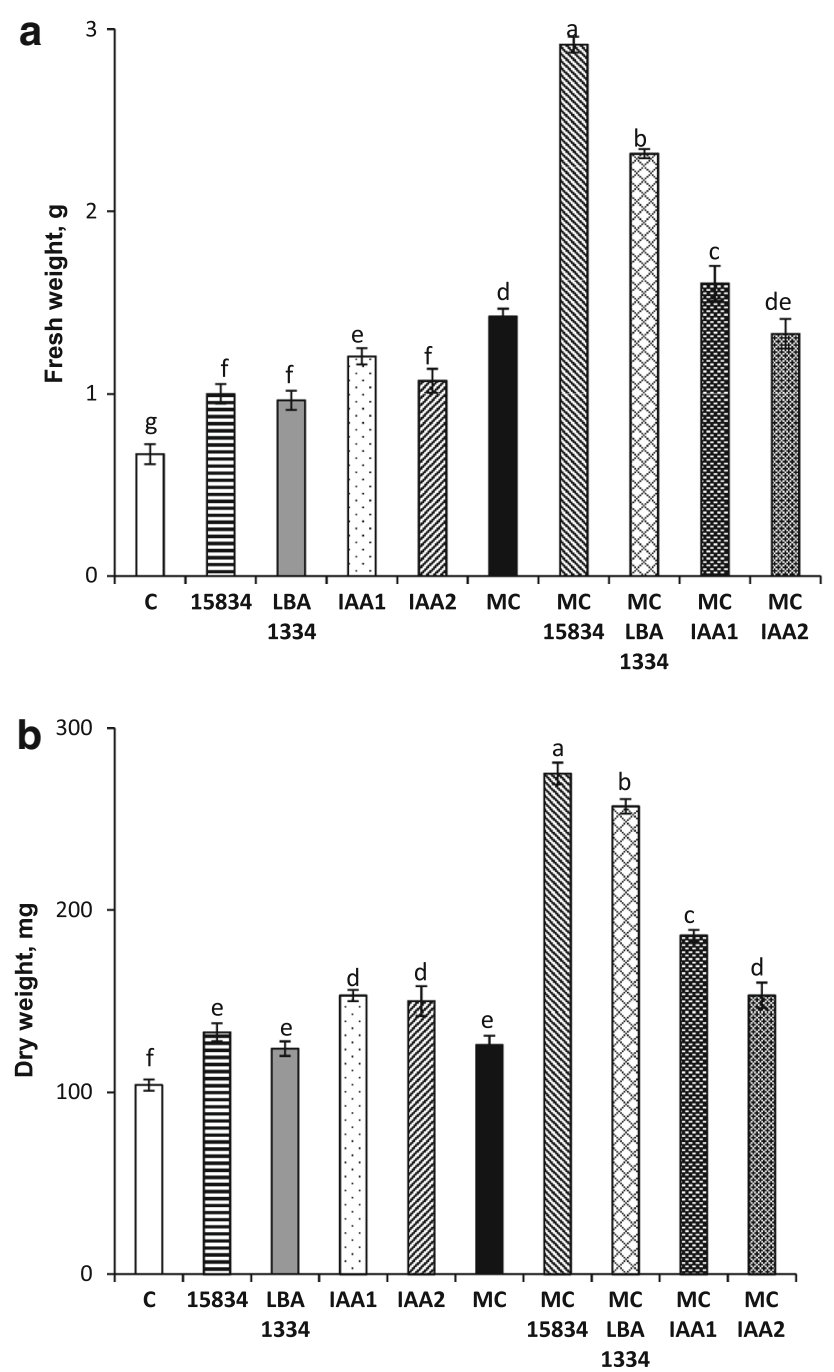

Fig. 5 Effect of $1 \mathrm{~h}$ seed soaking in bacterial suspension/IAA solutions and seed preconditioning for 5 days in the presence of Micro-Cel E and bacterial suspension/IAA solutions on seedling fresh (a) and dry (b) weight after 14 days in growth chamber (15/9 day/ night photoperiod) at $25^{\circ} \mathrm{C}$. $C$ control, 15834 A. rhizogenes strain 15834, LBA1334 A. rhizogenes strain LBA1334, IAA 1 IAA $2.3 \mu \mathrm{g} /$ $\mathrm{ml}$, IAA 2 IAA $0.38 \mu \mathrm{g} / \mathrm{ml}, M C$ matriconditioning, MC15834 A. rhizogenes strain $15834+\mathrm{MC}$, MCLBA1334 A. rhizogenes strain LBA $1334+$ MC, MC IAA 1 IAA $2.3 \mu \mathrm{g} / \mathrm{ml}+$ MC, MC IAA 2 IAA $0.38 \mu \mathrm{g} / \mathrm{ml}+\mathrm{MC}$. Vertical bars indicate \pm SD. Means with identical letters are not significantly different at $p<0.05$ (Duncan's multiple range test

stimulated the root length, but also enhanced the root architecture. After 14 days of seedling growth under gnotobiotic conditions, a beneficial effect of the treatment described above, visible as the development of numerous lateral and hair roots, was observed. However, exogenous IAA treatment retarded the growth and branching of roots; moreover, the roots were purple-coloured (Fig. 4). The beneficial effect of bio-priming by soaking and during matriconditioning was confirmed when fresh (Fig. 5a) and dry weights (Fig. 5b) were determined. The fresh weight of seedlings obtained from all the seed pre-treatments was greater than that of the untreated control (Fig. 5a). The most effective in this respect was seed conditioning in the presence of the two bacterial strains (15384 and LBA 1334): the fresh weights were about 4.4 and 3.5 times higher than that of the control, respectively. Similarly, in the case of dry weight, the best results were obtained when the seeds were conditioned simultaneously in the presence of bacteria and Micro-Cel E (Fig. 5b).

The beneficial effect of bio-priming by soaking and during matriconditioning was particularly evident when the development of seedlings in soil was analysed (Figs. 6, 7). After 14 days, the number of emerged seedlings obtained from the seeds soaked for $1 \mathrm{~h}$ in bacterial suspension (Fig. 6, upper panel), their length and branching of roots were the highest compared to the seedlings developed from seeds soaked in IAA solutions and water (Fig. 6, bottom panel). However, the bacterial strains present during 5 days of matriconditionig produced the most promising results and induced the best seedling emergence and growth (Fig. 7, upper panel). This stimulatory effect was a consequence of root development; the soil was overgrown by numerous branched roots which formed a compact mass (Fig. 7, bottom panel).

\section{Discussion}

This study employed a number of approaches to test the utility of pathogenic A. rhizogenes wild strains 15834 and LBA 1334 to be used as inocula in $F$. rubra grass: the grass seeds were soaked in bacterial suspensions or were conditioned in the presence of both a bacterial suspension and synthetic calcium silicate hydrate (Micro-Cel E). The approaches included screening of the phytopathogenic bacterium strains used, responsible for induction of hair root syndrome in plants, for in vitro auxin biosynthesis and deaminase ACC activity and for their growth-promoting activity during seed germination and under gnotobiotic (axenic) and soil conditions.

This work demonstrated, for the first time, that the phytopathogenic bacterium A. rhizogenes, responsible for induction of hair root syndrome in plants, could be effectively applied to seeds to accelerate their germination (increase germination dynamics) as well as to enhance seedling emergence and development (length of seedlings, blade and roots; fresh and dry weight). The beneficial effect on the processes discussed above was visible not only when seeds of $F$. rubra were soaked for $1 \mathrm{~h}$ in bacterial suspensions, but especially when the bacteria were present for 5 days during conditioning with a synthetic carrier, a calcium silicate hydrate known as Micro-Cel E. Although 5 days of conditioning with Micro-Cel E alone clearly improved seed germination and seedlings growth, 


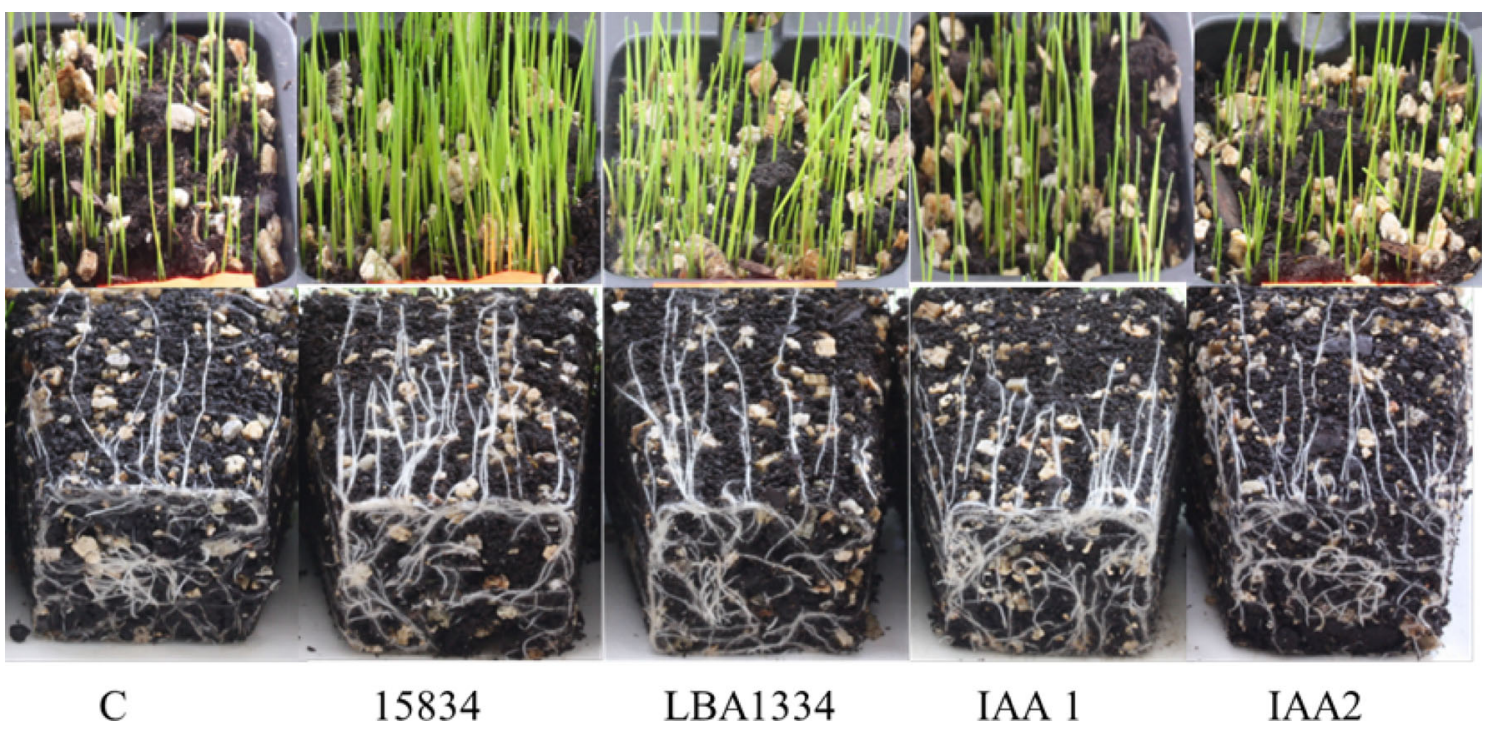

Fig. 6 Effect of $1 \mathrm{~h}$ red fescue seed soaking in bacterial suspension/ IAA solutions on the growth of seedlings (upper panel) after 14 days in soil. Images in the bottom panel show a root ball. The seedlings were grown in growth room (15/9 day/night photoperiod) at $25{ }^{\circ} \mathrm{C}$. $C$ control, 15834 A. rhizogenes strain 15834, LBA1334 A. rhizogenes strain 1334, IAA 1 IAA $2.3 \mu \mathrm{g} / \mathrm{ml}$, IAA 2 IAA $0.38 \mu \mathrm{g} / \mathrm{ml}$

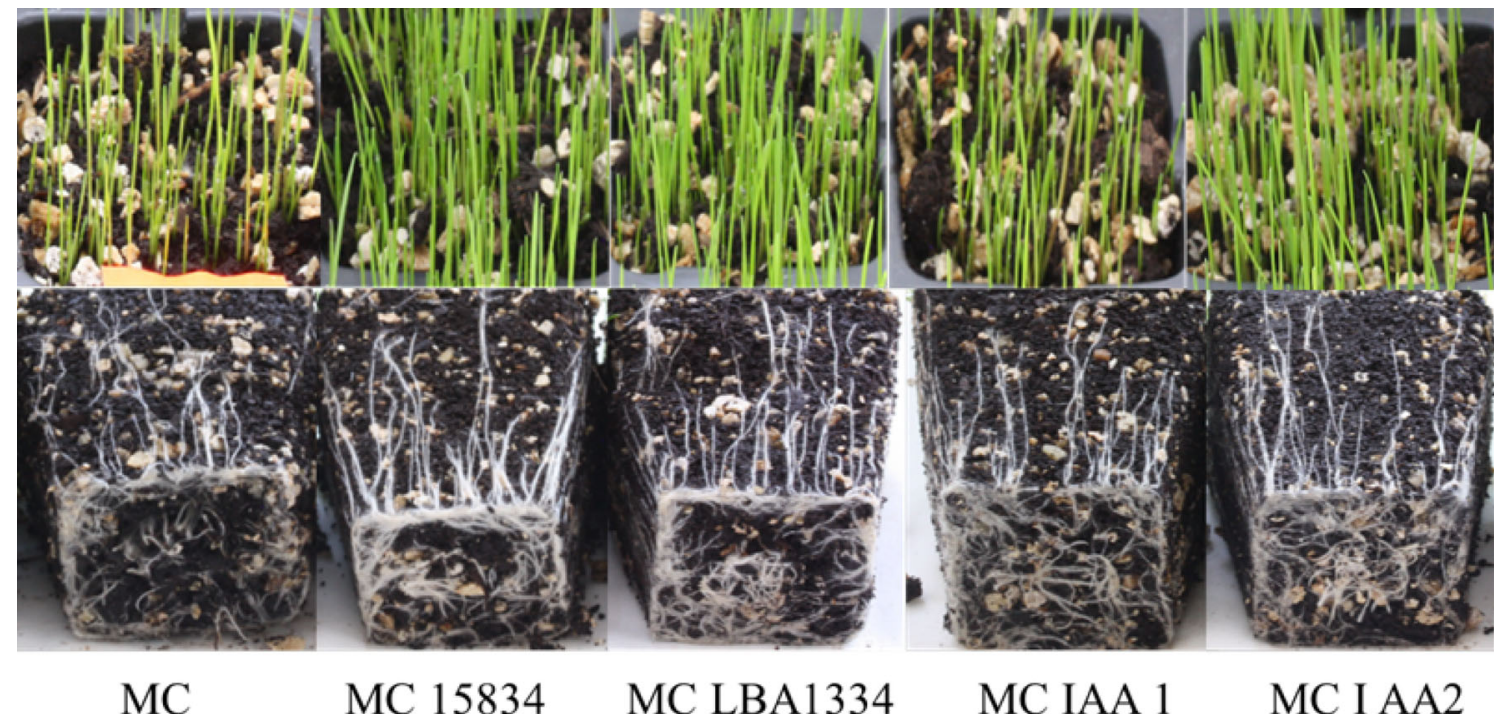

Fig. 7 Effect of red fescue seed preconditioning for 5 days in the presence of Micro-Cel E and bacterial suspension/IAA solutions on the growth of seedlings (upper panel) after 14 days in soil. Images in the bottom panel show a root ball. The seedlings were grown in

the presence of wild 15834 and LBA 1334 strains of the bacterium during the matriconditioning increased the beneficial effect of the processes described. Upon inoculation of grass seeds during priming, the main effect observed was an increase of the number of root hairs and lateral roots. The increase of seedling growth correlated positively with the improved root development (Fig. 4). On the one hand, our results are in line with findings of other workers who assessed the inoculation effect of non- growth room (15/9 day/night photoperiod) at $25^{\circ} \mathrm{C}$. $M C$ matriconditioning, MC15834 A. rhizogenes 15834 strain + MC, MCLBA1334 A. rhizogenes LBA1334 strain $+\mathrm{MC}, M C$ IAA 1 IAA $2.3 \mu \mathrm{g} / \mathrm{ml}+$ MC, $M C$ IAA 2 IAA $0.38 \mu \mathrm{g} / \mathrm{ml}+\mathrm{MC}$

pathogenic plant growth-promoting bacteria (PGPR) on the growth of many plants (Glick 1995; Martinez-Viveros et al. 2010; Rashid et al. 2011; Glick 2012), whereas, and on the other, the results obtained are consistent with previous studies on seeds of some grasses (Hardegree 1994; Madakadze et al. 2000) and vegetables such onion and tomato (Kępczyńska et al. 2003a, 2007) which showed the increased germination rates and seedling emergence in matric-primed seeds. 
The beneficial physiological (accelerated germination and emergence) and morphological (root architecture) changes observed upon inoculation of $F$. rubra seeds with rhizobacteria have been attributed to the bacterial capacity of producing IAA, one of the most well-known phytohormone, because of its important role in the initial processes of lateral and adventitious root formation and root elongation (Patten and Glick 2002).

The production of phytohormones, including auxins, by PGPR is now considered to be one of the most important mechanisms by which many non-pathogenic rhizobacteria (PGPR) promote plant growth (Spaepen et al. 2007; Spaepen and Vanderleyden 2010). The pathogenic bacterium $A$. rhizogenes is also known to synthesize IAA from tryptophan via the indole-3-acetamide pathway, which has been implicated in hair root syndrome induction in plants (Spaepen and Vanderleyden 2010). It is well-established that an in vitro $A$. rhizogenes infection at the base of microcuttings can improve the rooting of fruit species such as almond, apple, plum, kiwi (Damiano and Monticelli 1998), banana (Mahmood et al. 2010) and trees such as Pinus and Larix (McAfee et al. 1993; Haggman and Aronen 2000). Under field and greenhouse conditions, too, positive effects on rooting rate, root length and dry weight of vegetable semi-hardwood mint cuttings were observed after inoculation with Agrobacterium rubi (Kaymak et al. 2008). The susceptibility of plants to A. rhizogenes varies greatly and depends on the strain (type of opines produced-agropine, mannopine, cucumopine, mikimopine) and on the host plant genotype (Estrada-Navarrete et al. 2006). These authors tested four $A$. rhizogenes strains to induce hair roots on four species of Phaseolus, strain K599 (cucumopine-type) proving the most effective in the process. However, the agropine- (A4 and A15834) and other cucumopine-type (A2659) strains of the bacterium performed hairy root induction poorly. Although Estrada-Navarrete et al. (2006) did not check the IAA production; it is possible that the efficiency of these strains depends on the ability to produce IAA. This short review shows that the bacteria were used for the induction of rooting of wounded cuttings by infection at the base of these micro-cuttings, but have never been used in seed treatments. In our experiments, two pathogenic agropine-type A. rhizogenes strains, 15834 and LBA1334, were used for priming of healthy, undamaged seeds, prior to radicle protrusion through the seed coat.

Although, in the absence of tryptophan, the ability of the bacteria to synthesize IAA was very low, supplementation of the medium with this IAA precursor considerably enhanced the IAA production by the strains studied. Earlier observations showed that, following storage in mineral oil, the capacity of rhizobacteria to synthesize and release auxins was decreased or even lost only when the medium was supplemented with tryptophan (Tsavkelova et al. 2005). Our strains produced different amounts of IAA in the presence of $200 \mu \mathrm{g} / \mathrm{ml}$ tryptophan, strain 15834 producing about 8 times more IAA than strain LBA 1334.

Shokri and Emtiazi (2010) observed that, depending on the $A$. rhizogenes strain, IAA production varied several fold, regardless of the medium type: strain A4 (agropinetype) produced $2.78 \mathrm{ppm}$ IAA/mg biomass, while LBA 9402 (identical type) about six times less. Similarly, Agrobacterium tumefaciens, another phytopathogenic bacterium that causes crown gall disease of plants, is able to produce, in the presence of $200 \mu \mathrm{g} / \mathrm{ml}$ tryptophan, different amounts of IAA depending on the strain: strain BW62UT1570 produced $40.5 \mu \mathrm{g} / \mathrm{ml}$ IAA, whereas strain WR41 produced about 2 times less (Rashid et al. 2011).

Our results may suggest that IAA production by the two strains, 15834 and LBA1334, of A. rhizogenes can be responsible for stimulation of grass root development. The roots from seeds primed in the presence of strains 15834 and LBA 1334 were, on the average, by 164 and $84 \%$ longer, respectively, than the roots of the non-inoculated control seeds after 7 days. Strain 15834 producing 8 times more IAA than LBA 1334 was more effective in stimulating the seedling and root growth and weight increase, compared to strain LBA 1334 when the inoculated seeds were matriconditioned. A similarly beneficial effect of the strain was also observed in the fresh and dry seedling weight. A similar relationship was reported when canola seeds were inoculated for $1 \mathrm{~h}$ with two A. tumefaciens strains, BW62UT1570 and WR41; strain BW62UT1570 producing more IAA caused a higher root elongation, compared with strain WR41 (Rashid et al. 2011). Moreover, Patten and Glick (2002) showed that the primary roots of canola seedlings grown from seeds treated with wild-type Pseudomonas putida GR12-2 with ability to produce IAA were, on the average, by 35-50\% longer than the roots from seeds treated with an IAA-deficient mutant and the roots from uninoculated seeds.

However, the auxin production by rhizobacteria is not the only important mechanism by which the bacteria promote plant growth. The ability to degrade ACC, the ethylene precursor, in the rhizosphere is another important mechanism of beneficial effects of bacteria in plant growth promotion (Glick et al. 2007). Ethylene is well-known to exert different effects on plant growth, the effects being dependent on ethylene concentration in root tissues. At a high concentration, stem and root growth is inhibited. Under different types of environmental stress, including infections with pathogens (i.a., Agrobacterium), plants are known to respond by synthesizing ACC (Wachter et al. 1999); some of ACC produced is secreted into the rhizoshpere and reabsorbed by the roots, and converted to ethylene there. Moreover, agropine-type $A$. rhizogenes strains A4 and LBA9402 have been demonstrated 
to produce ethylene under in vitro conditions, and inoculation of petunia explants with these strains increased ethylene production by the explants (Kępczyńska et al. 2003b). The enhanced ethylene production appears to be a secondary outcome of auxin synthesis in plant tissues due to the transformation of the plant with the IAA in T-DNA encoding oncogenic genes. Kępczyńska et al. (2003b) observed also that ethylene present in flasks used to culture hairy roots of Petunia hybrida inhibited root growth, the inhibition being alleviated by ethylene trapping with $\mathrm{KMnO}_{4}$. Thus, ethylene accumulation in the rhizosphere can result in poor root growth, which leads to a diminished ability to take up water and nutrients. Therefore, the presence in the two A. rhizogenes strains of ACC deaminase (ACCD), an enzyme breaking down ACC exuded from plants, can diminish or prevent some of the harmful effects of the high, 'stressful', ethylene levels. The in vitro ACC deaminase activity assay showed relatively high levels of the enzyme's activity in A. rhizogenes strains 15834 and LBA 1334 (1.72 and $0.92 \mu \mathrm{mol} \alpha$-ketobutyrate/mg protein/h, respectively), compared with $A$. tumefaciens strain D3, another bacterium also from the family Rhizobiaceae, which showed the activity of $0.47 \mu \mathrm{mol} \alpha$-ketobutyrate/mg protein/h (Hao et al. 2011). The A. rhizogenes activities were about 4 and 2 times that of $A$. tumefaciens $\mathrm{D} 3$, respectively. Different soil bacteria, including representatives of the genera Rhizobium (a member of the family Rhizobiaceae as well) synthesize ACCD (Glick et al. 1998; Duan et al. 2009). Patten and Glick (2002) suggested that IAA and ACCD work in concert to stimulate root elongation. Exogenous IAA is known to increase transcription and activity of ACC synthase (Peck and Kende 1995) which catalyzes the ACC synthesis in plants. In turn, ACC stimulates ACCD activity in bacteria ( $\mathrm{Li}$ and Glick 2001). The higher stimulation of grass seedling growth observed, especially that of roots, after priming with A. rhizogenes strain 15834 , compared to strain 1334 , is probably related to IAA production by this strain rather than to the activity of ACC deaminase. Although the ACCD activity in strain LBA 1334 was twice that in 15834, grass growth promotion was weaker, compared to the beneficial effect of strain 15834 which showed a 7 times higher IAA production. However, a gnotobiotic canola root elongation assay showed an avirulent strain D3 of A. tumefaciens to be able to promote root growth, while the A. tumefaciens acdS knockout mutant strain D3-1 lacking ACCD activity was not able to produce such effect (Hao et al. 2011).

\section{Conclusions}

The use of pathogenic agropine-type A. rhizogenes strains 15834 and LBA 1334 to seeds to soak them in, but especially by applying the bacteria during 5-day priming in the presence of the Micro-Cel E carrier can be a successful approach to improve red fescue seed germination and seedling growth, mainly through the development of the root system. A rapid establishment of roots is beneficial to young seedlings of turf grasses, including $F$. rubra L., and is responsible for obtaining good quality and durable lawns. Improvement of seedling development, particularly visible in root architecture, is produced because the bacteria strains used are able to produce IAA, a known stimulant of root development, and deaminase ACC which probably prevents the root growth-inhibiting levels of ethylene induced by bacterial IAA or exogenous IAA. Exposure of grass seeds to exogenous concentrations identical to those produced by bacterial strains showed the bacterial IAA and not the synthetic hormone to play a major role in the $F$. rubra seed germination and seedling development, mainly via the development of the root system. Thus, the beneficial effect of pathogenic A. rhizogenes strains on seed germination and seedling development, mainly on their root growth and branching, could be a cumulative effect of IAA and ACC deaminase.

Simultaneous application of bio- and matripriming is a good presowing seed treatment technique for the rapid establishment of roots which is advantageous for young grass seedlings, as it increases their anchoring ability in the soil. The total root surface increase obtained (Figs. 6, 7) leads to an enhanced mineral uptake from the soil, and root exudates further stimulate root colonization by PGPR.

Author contribution EK designed research, analyzed data and wrote the paper. PK conducted experiments with $\mathrm{MC}$ and bacteria during MC, seed germination and seedling growth, prepared figures and photos, analysed data and carried out statistical analysis. JA carried out analysis of ACCD activity and IAA production.

Acknowledgments This work was partially supported by the National Scientific Center (NCN) Grant No. NN310784140. Both the A. rhizogenes strains were a kind gift from Prof. Ewa Łojkowska (Intercollegiate Faculty of Biotechnology, University of GdańskMedical University of Gdańsk). We are indebted to Dr. Teresa Radziejewska for linguistic assistance.

Open Access This article is distributed under the terms of the Creative Commons Attribution License which permits any use, distribution, and reproduction in any medium, provided the original author(s) and the source are credited.

\section{References}

Bashan Y (1998) Inoculants of plant growth-promoting bacteria for use in agriculture. Biotechnol Adv 16(4):729-770

Bennett AJ, Whipps JM (2008) Dual application of beneficial microorganisms to seed during drum priming. Appl Soil Ecol 38:83-89

Bhattacharyya PN, Jha DK (2012) Plant growth-promoting rhizobacteria (PGPR): emergence in agriculture. World J Microbiol Biotechnol 28:1327-1350 
Bradford M (1976) A rapid and sensitive method for the quantification of microgram quantities of protein utilizing the principle of protein-dye binding. Anal Biochem 72:248-254

Chilton MD, Tepfer DA, Petit A, David C, Casse-Delbert F, Tempe J (1982) Agrobacterium rhizogenes inserts T-DNA into the genome of the host plant root cells. Nature 295:432-434

Damiano C, Monticelli S (1998) In vitro fruit trees rooting by Agrobacterium rhizogenes wild type infection. Electron $\mathrm{J}$ Biotechn 1:1-7

Duan J, Müller KM, Charles TC, Vesley S, Glick BR (2009) 1-aminocyclopropane-1-carboxylate (ACC) deaminase genes in rhizobia from southern Saskatchewan. Microb Ecol 57:421-422

Estrada-Navarrete G, Alvarado-Affantranger X, Oliveras JE, DiazCamino C, Santana O, Murillo E, Guillen G, Sanchez-Guevara N, Acosta J, Quinto C, Li D, Gresshoff PM, Sanchez F (2006) Agrobacterium rhizogenes transformation of the Phaseolus spp.: a tool for functional genomics. Mol Plant Microbe In 19:1385-1393

Gholami A, Shahsavani S, Nezarat S (2009) The effect of plant growth promoting rhizobacteria (PGPR) on germination, seedling growth and yield of maize. Proc World Acad Sci Eng Tech 49:19-24

Glick BR (1995) The enhancement of plant growth by free living bacteria. Can J Microbiol 41:109-111

Glick BR (2012) Plant growth-promoting bacteria: mechanism and applications. Hindawi Publishing Corporation. Scientifica ID 963401. doi:10.6064/2012/963401

Glick BR, Penrose DM, Li J (1998) A model for the lowering of plant ethylene concentrations by plant growth-promoting bacteria. J Theor Biol 190:63-68

Glick BR, Todorovic B, Czarny J, Cheng Z, Duan J, McConkey B (2007) Promotion of plant growth by bacterial ACC deaminase. Crit Rev Plant Sci 26:227-242

Grant JE, Dommisse EM, Conner AJ (1991) Gene transfer to plant using Agrobacterium. In: Murray DR (ed) Advanced methods in plant breading and international biotechnology. $\mathrm{CAB}$ International, Wallingford, pp 50-73

Haggman HM, Aronen TS (2000) Agrobaterium rhizogenes for rooting recalcitrant woody plants. In: Jain SM, Minocha SC (eds) Molecular biology of woody plants, V 2. Kluwer Academic Publishers, New York, pp 47-78

Hao Y, Charles TC, Glick BR (2007) ACC deaminase from plant growth-promoting bacteria affects crown gall development. Can J Microbiol 53:1291-1299

Hao Y, Chareles TC, Glick BR (2011) ACC deaminase activity in avirulent Agrobacterium tumefaciens D3. Can J Microbiol 57:278-286

Hardegree SP (1994) Matric priming increase germination rate of great basin native perennial grasses. Agron J 86:289-293

Honma M, Shimomura T (1978) Metabolism of 1-aminocyclopropane-1-carboxylic acid. Agric Biol Chem 42:1825-1831

Kaymak HC, Yarali F, Guvenc I, Donmez MF (2008) The effect of inoculation with plant growth rhizobacteria (PGPR) on root formation of mint (Mentha piperita L.) cuttings. Afr J Biotechnol 7(24):4479-4483

Kępczyńska E, Piękna-Grochala J, Kępczyński J (2003a) Effects of matriconditioning on onion seed germination, seedling emergence and associated physical and metabolic events. Plant Growth Regul 41:269-278

Kępczyńska E, Zielińska S, Kępczyński J (2003b) Ethylene production by Agrobacterium rhizogenes strains in vitro and in vivo. Plant Growth Regul 39:13-17

Kępczyńska E, Piękna-Grochala J, Kępczyński J (2007) Seed germination of two tomato cultivars following matriconditioning under optimal and stress temperatures. Seed Sci Technol 35(3):749-753
Khalid A, Arshad M, Zahir ZA (2004) Screening plant growthpromoting rhizobacteria for improving growth and yield of wheat. J App Microbiol 96:473-480

Khan AA (1992) Preplant physiological seed conditioning. In: Janick J (ed) Horticultural reviews. John Wiley \& Sons, New York, pp 131-181

Khan AA, Miura H, Prusiński J, Ilyas S (1990) Matriconditioning of seeds to improve emergence. In: Proceedings of National Symposium Stand Establishment Horticultural Crops, Minneapolis pp $19-40$

Li J, Glick BR (2001) Transcriptional regulation of the Enterobacter cloacae UW 1-aminocyclopropane-1-carboxylate (ACC) deaminase gene (acdS). Can J Microbiol 47:359-367

Lucy M, Reed E, Glick BR (2004) Application of free living plant growth-promoting rhizobacteria. Anton Leeuw Int J G 86:1-25

Madakadze IC, Prithviray B, Madakadze RM, Steward K, Peterson P, Coulman BE, Smith DL (2000) Effect of preplant seed conditioning treatment on the germination of switch grass (Panicum virgatum L.). Seed Sci Technol 28(2):403-411

Mahmood M, Rahman ZA, Saud HM, Shamsuddin ZH, Subramaniam S (2010) Influence of rhizobacterial and agrobacterial inoculation on selected physiological and biochemical changes of banana cultivar, berangan (AAA) plantlets. J Agr Sci 2(1):115-137

Martinez-Viveros O, Jorquera MA, Crowley DE, Gajardo G, Mora ML (2010) Mechanism and practical considerations involved in plant growth promotion by rhizobacteria. J Soil Sci Plant Nutr 10:293-319

McAfee BJ, White EE, Pelcher LE, Lapp MS (1993) Root induction in pine (Pinus) and larch (Larix) spp. using Agrobacterium rhizogenes. Plant Cell Tiss Org 34:53-62

Miller JH (1976) Experiments in molecular genetics. Cold Spring Harbor Laboratory, New York

Patten ChL, Glick BR (2002) Role of Pseudomonas putida indole acetic acid in development of the host plant root system. Appl Environ Microb 68:3795-3801

Peck SC, Kende H (1995) Sequentional induction of the ethylene biosynthesis enzyme by indole-3-acetic acid in etiolated peas. Plant Mol Biol 28:293-301

Penrose DM, Glick BR (2003) Methods for isolating and characterizing ACC deaminase containing plant growth-promoting rhizobacteria. Physiol Plantarum 118:10-15

Rashid S, Charles TC, Glick BR (2011) Isolation and characterization of new plant growth-promoting bacterial endophytes. Appl Soil Ecol 61:217-224

Sarmast MK, Salehi H, Khosh-Khui M (2012) Micropropagation of Araucaria excelsa $\mathrm{R}$. Br. var. glauca Carrière from orthotropic stem explants. Physiol Mol Biol Plants 18(3):265-271

Sarwar M, Arshad M, Martens DA, Frankenberger WT Jr (1992) Tryptophan-dependent biosynthesis of auxins in soil. Plant Soil 147:207-215

Shokri D, Emtiazi G (2010) Indole-3-acetic acid (IAA) production in symbiotic and non-symbiotic nitrogen-fixing bacteria and its optimization by Taguchi design. Curr Microbiol 61:217-225

Spaepen S, Vanderleyden J (2010) Auxin and plant-microbe interactions. Cold Spring Harb Perspect Biol. doi:10.1101/cshperspect. a001438

Spaepen S, Vanderleyden J, Remans R (2007) Indole-3-acetic acid in microbial and microorganism plant signalling. FEMS Microbiol Rev 31:425-448

Tepfer D (1990) Genetic transformation using Agrobacterium rhizogenes. Physiol Plantarum 79:140-146

Tsavkelova EA, Cherdyntseva TA, Netrusov AL (2005) Auxin production by bacteria associated with orchid roots. Mikrobiologiia 74(1):55-62 
Verma JP, Yadav J, Tiwari KN, Sing L, Singh V (2010) Impact of plant growth promoting rhizobacteria on crop production. Int $\mathbf{J}$ Agric Res 5:954-983

Wachter R, Fisher K, Gabler R, Kuhnemann F, Urban W, Bogemann GM (1999) Ethylene production and ACC accumulation in Agrobacterium tumefaciens- induced plant tumors and their impact on tumours and host stem structure and function. Plant Cell Environ 22(10):1263-1273
Whipps JM (2001) Microbial interaction and biocontrol in the rhizosphere. J Exp Bot 52:487-511

Yamamoto I, Turgeon AJ, Duich JM (1997) Seedling emergence and growth of solid matrix primed Kentucky bluegrass seed. Crop Sci 37:225-229 